\title{
POLA MAKAN, STATUS SOSIAL EKONOMI KELUARGA DAN PRESTASI BELAJAR PADA ANAK STUNTING USIA 9-12 TAHUN DI KEMIJEN SEMARANG TIMUR
}

\author{
Febrian Saniarto, Binar Panunggal ${ }^{*}$ \\ Program Studi Ilmu Gizi Fakultas Kedokteran Universitas Diponegoro \\ Jl.Dr.Sutomo No.18, Semarang, Telp (024) 8453708, Email : gizifk@undip.ac.id
}

\begin{abstract}
Background: Stunting occurred due to chronic malnutrition which can lead to cognitive impairment. Cognitive impairment resulted to lower academic achievement in children. However, there were a lot of factors determines children's academic achievement. Dietary pattern and family's socioeconomic status were associated with children's academic achievement. This study aimed to determine the association of dietary pattern and family's socioeconomic status with academic achievement of 9-12 years old stunted children in Kemijen East Semarang.

Methods: The subjects of this study were 9-12 years old stunted children. Total of 85 children participated in this cross-sectional study. Subjects and respondents were interviewed to obtain characteristics data, dietary pattern and family's socioeconomic indicators like parent academic level, employment status and family's outcome per capita. Canada's Food Guide to Healthy Eating (CFGHE) was used to categorize the child's dietary pattern. The academic achievement was obtained from Natural Science, Mathematics, and Indonesian scores.

Results: This study found that more than half of the students had low academic achievement (52,9\%). Nearly half of them had poor dietary pattern (40\%) and more than half had average dietary pattern (58,8\%). Most of the subject had low educated parent (mother 74,1\% and father 61,2\%). As much as 61,2\% subject's family had low outcome per capita. Bivariate analysis found that dietary pattern and family socioeconomic status were not related to academic achievements ( $p>0.05)$.

Conclusion: Dietary pattern and family's socioeconomic status were not related to the academic achievement of 912 years old stunted children in Kemijen East Semarang.
\end{abstract}

Key words: dietary pattern; socioeconomic; academic achievement; stunting

\section{ABSTRAK}

Latar belakang: Stunting pada anak usia sekolah dasar (9-12 tahun) terjadi karena malnutrisi kronis. Malnutrisi kronis juga berakibat pada terlambatnya perkembangan otak. Hal ini berakibat pada rendahnya kemampuan kognitif dan rendahnya prestasi belajar. Namun ada banyak faktor yang mempengaruhi prestasi belajar anak. Pola makan dan status sosial ekonomi keluarga adalah faktor yang berhubungan dengan prestasi belajar pada anak. Penelitian ini dilakukan untuk mengetahui hubungan pola makan dan status sosial ekonomi keluarga dengan prestasi belajar anak stunting usia 9-12 tahun di Kemijen Semarang Timur.

Metode: Sebanyak 85 anak stunting usia 9-12 tahun berpartisipasi dalam penelitian cross sectional ini. Subjek dan responden (orang tua subjek) diwawancarai untuk mendapatkan data karakteristik subjek, pola makan, dan status sosial ekonomi keluarga yang meliputi pendidikan, pekerjaan orang tua, dan pendapatan yang dilihat dari pengeluaran perkapita. Canada's Food Guide to Healthy Eating (CFGHE) digunakan untuk mengkategorikan pola makan anak. Sementara data prestasi belajar diperoleh dari nilai raport mata pelajaran IPA, Matematika dan Bahasa Indonesia.

Hasil: Sebanyak 52,9\% subjek memiliki prestasi belajar kurang. Hampir setengah dari subjek memiliki pola makan yang buruk (40\%) dan lebih dari setengah memiliki pola makan sedang (58,8\%). Sebagian besar orang tua subjek berpendidikan rendah (ibu 74,1\% dan ayah 61,2\%). Sebanyak 61,2\% keluarga mempunyai pengeluaran perkapita yang rendah. Analisis bivariat menunjukkan bahwa tidak terdapat hubungan antara pola makan dan status sosial ekonomi keluarga dengan prestasi belajar anak stunting usia 9-12 tahun.

Kesimpulan: Pola makan dan status sosial ekonomi keluarga tidak berhubungan dengan prestasi belajar anak stunting usia 9-12 tahun di Kemijen Semarang Timur.

Kata kunci: pola makan; sosial ekonomi; prestasi belajar; stunting

\section{PENDAHULUAN}

Stunting

pertumbuhan linier yang disebabkan oleh malnutrisi kronis, yang dinyatakan dengan nilai zskor tinggi badan menurut umur (TB/U) kurang dari -2 standar deviasi (SD) berdasarkan standar yang ditetapkan oleh World Health Organization (WHO). ${ }^{1}$ Stunting pada anak sekolah merupakan manifestasi dari stunting pada masa balita yang mengalami kegagalan dalam tumbuh kejar (catch up growth), defisiensi zat gizi dalam jangka waktu yang lama, serta adanya penyakit infeksi. 
Prevalensi anak stunting di Indonesia masih tinggi. Pada tahun 2010 prevalensi anak stunting pada usia 6-12 tahun adalah 35,6\% dengan rincian $15,1 \%$ sangat pendek dan $20,5 \%$ pendek. Angka ini terbilang tinggi mengingat standar WHO untuk anak stunting (sangat pendek dan pendek) adalah 20\%. ${ }^{3}$ Prevalensi anak stunting usia sekolah (6-12 tahun) di Provinsi Jawa Tengah mencapai $34,1 \%$. Di Semarang, prevalensi anak stunting pada usia 2-3 tahun mencapai $20,7 \%$ dengan kejadian tertinggi di Semarang Timur yaitu $40,2 \%$. $^{4}$

Stunting berkaitan dengan rendahnya kemampuan kognitif anak. Pemenuhan kebutuhan akan zat gizi yang tidak adekuat dalam jangka waktu yang lama berdampak pada tidak optimalnya perkembangan jaringan dan otak. Hal ini menyebabkan terjadi keterlambatan pematangan fungsi otak. Terganggunya pematangan fungsi otak dalam jangka waktu yang lama berhubungan dengan rendahnya kemampuan kognitif anak berkaitan dengan malnutrisi. ${ }^{5}$

Penelitian mengenai hubungan antara status gizi dengan kognitif telah banyak dilakukan. Penelitian di Brazil dan Maroko menunjukkan bahwa anak usia sekolah dasar (6-15 tahun) yang stunting memiliki kemampuan kognitif yang lebih rendah, nilai matematika yang lebih rendah, dan skor IQ yang lebih rendah dibandingkan dengan anak non-stunting. ${ }^{6-8}$ Penelitian di Filipina juga menunjukkan bahwa nilai z-skor tinggi badan menurut umur berkorelasi positif dengan skor IQ. Semakin rendah z-skor TB/U semakin rendah pula skor IQ. ${ }^{9}$ Selain itu, stunting juga berhubungan dengan keterlambatan usia masuk sekolah, pengulangan kelas, prestasi belajar, dan dropout dari sekolah. ${ }^{9,10}$

Beberapa penelitian menunjukkan bahwa status gizi stunting berhubungan dengan prestasi belajar anak sekolah, akan tetapi banyak faktor lain yang mempengaruhi prestasi belajar anak. Faktor yang mempengaruhi prestasi belajar anak diantaranya kualitas sekolah, karakteristik keluarga seperti status sosial ekonomi dan pendidikan orang tua, serta karakteristik anak. ${ }^{11}$ Penelitian mengenai pengaruh asupan terhadap prestasi belajar telah dilakukan di beberapa negara. Di Taiwan, anak Sekolah Dasar dengan kebiasaan makan makanan yang berkualitas rendah seperti makanan manis dan makanan yang digoreng, dan jarang mengkonsumsi sayur, buah, ikan dan telur, berhubungan dengan rendahnya prestasi di sekolah. ${ }^{12}$ Penelitian di Kanada dan Palestina menunjukkan bahwa ada hubungan positif antara konsumsi buah dan sayur dengan prestasi belajar. ${ }^{11,13}$

Sosial-ekonomi keluarga juga berpengaruh terhadap prestasi anak di sekolah. Sebuah penelitian di Kanada menunjukkan bahwa perbedaan status sosial ekonomi kelurga berhubungan dengan nilai matematika siswa. ${ }^{12}$ Semakin tinggi tingkat sosial ekonomi, pendidikan orang tua, dan pendapatan keluarga maka semakin baik prestasi belajar anak . ${ }^{6,14,15}$

Beberapa penelitian mengenai pola makan dan status sosial ekonomi serta hubungannya dengan prestasi belajar anak di atas menggunakan subjek anak normal atau tidak mempermasalahkan status gizi anak yang menjadi subjek penelitian dan belum ada penelitian yang mengkhususkan kepada anak stunting. Padahal dibutuhkan pengetahuan mengenai faktor yang dapat mempengaruhi prestasi belajar anak stunting sehingga dapat mengoptimalkan kemampuan anak tersebut. Penelitian ini bertujuan untuk mengetahui hubungan pola makan, status sosial ekonomi keluarga dan prestasi belajar pada anak stunting usia 9-12 tahun di kelurahan Kemijen Semarang Timur. Penelitian ini dilakukan di kelurahan Kemijen Semarang Timur karena pada observasi awal ditemukan banyak anak usia SD yang mengalami stunting.

\section{METODE PENELITIAN}

Penelitian cross sectional ini termasuk dalam ruang lingkup keilmuan gizi masyarakat. Penelitian ini dilakukan di Kelurahan Kemijen, Kecamatan Semarang Timur, Kota Semarang pada bulan September-Oktober 2013. Sampel diambil dari siswa empat Sekolah Dasar Negeri di Kelurahan Kemijen, Semarang Timur, yaitu SDN Kemijen 01, SDN Kemijen 02, SDN Kemijen 03, dan SDN Kemijen 04. Pengambilan sampel diawali dengan skrining terhadap 834 anak keempat SD tersebut. Skrining dilakukan kepada anak kelas 3-6 SD. Hasil skrining diperoleh 161 anak berusia 9-12 tahun dengan z-skor tinggi badan menurut umur $(\mathrm{TB} / \mathrm{U}) \leq-2 \mathrm{SD}$ menurut standar WHO 2007. Simple random sampling digunakan untuk mendapatkan sampel sebanyak 85 anak.

Variabel terikat penelitian ini yaitu prestasi belajar anak stunting usia 9-12 tahun, variabel bebas yaitu pola makan dan status sosial ekonomi keluarga anak stunting usia 9-12 tahun. Data primer yang dikumpulkan adalah data karakteristik subjek, data antropometri, data pola makan dan data status sosial ekonomi keluarga. 
Pengukuran antropometri tinggi badan menggunakan microtoise dengan ketelitian $0,1 \mathrm{~cm}$ dan berat badan menggunakan timbangan injak dengan ketelitian $0,1 \mathrm{~kg}$.

Data pola makan dan status sosial ekonomi keluarga diperoleh dengan wawancara terhadap subjek dan responden (orang tua subjek). Pola makan subjek didapat dari hasil wawancara menggunakan formulir FFQ semi-kuantitatif. Data ini kemudian dibandingkan dengan Canada's Food Guide to Healthy Eating (CFGHE), yaitu pedoman gizi dari Kanada. CFGHE digunakan sebagai dasar pengkategorian pola makan karena belum adanya pedoman di Indonesia yang dapat digunakan untuk menilai pola makan. CFGHE terdiri dari empat anjuran kelompok makanan yaitu kelompok makanan pokok, sayur dan buah, susu (susu, susu kedelai, keju, dan yogurt), serta daging dan alternatifnya (daging merah, daging unggas, ikan, telur, tahu, tempe). ${ }^{16}$ Menurut CFGHE anjuran asupan kelompok makanan pokok untuk satu hari adalah 6 porsi. Anjuran untuk kelompok sayur dan buah adalah 6 porsi, untuk susu dan produk olahannya 3 porsi dan untuk daging dan alternatifnya 2 porsi dalam sehari. Pola makan dikategorikan menurut jumlah anjuran yang sesuai dengan pedoman gizi tersebut menjadi pola makan buruk (memenuhi 0-1 anjuran), pola makan sedang (memenuhi 2-3 anjuran) dan pola makan baik (memenuhi 4 anjuran). ${ }^{17}$

Status sosial ekonomi keluarga dilihat dari tiga aspek yaitu pendidikan orang tua, pekerjaan orang tua, dan pendapatan yang dilihat dari pengeluaran perkapita keluarga. Pendidikan orang tua dikategorikan menjadi pendidikan rendah jika jenjang pendidikannya mulai dari tidak sekolah sampai tamat SMP dan pendidikan tinggi jika orang tua anak tamat SMA atau lebih tinggi. Pekerjaan orang tua dikategorikan menjadi bekerja dan tidak bekerja. Pengeluaran perkapita keluarga selama satu bulan dibandingkan dengan Pengeluaran Perkapita untuk Makanan dan Bukan Makanan Daerah Perkotaan Jawa Tengah yaitu Rp. 531.601,- dan dikategorikan menjadi pengeluaran perkapita tinggi dan pengeluaran perkapita rendah. Ketiga aspek sosial ekonomi ini diperoleh dari wawancara terhadap responden menggunakan kuesioner sosial ekonomi keluarga. ${ }^{18}$

Prestasi belajar anak diperoleh dari ratarata nilai raport semester terakhir subjek pada mata pelajaran Bahasa Indonesia, Matematika, dan IPA. Nilai rata-rata prestasi belajar per individu tersebut kemudian dikategorikan menjadi prestasi belajar "baik" jika rerata nilai individu sama dengan atau diatas nilai rerata kelas dan prestasi belajar "kurang" jika nilai rerata individu dibawah nilai rerata kelas. Pemilihan ketiga mata pelajaran yaitu Bahasa Indonesia, Matematika dan IPA dikarenakan ketiga mata pelajaran ini dapat digunakan untuk mengukur kemampuan kognitif anak. $^{19}$

Analisis bivariat menggunakan uji chisquare untuk mengetahui hubungan antara pola makan dengan prestasi belajar. Uji chi-square juga digunakan untuk mengetahui hubungan sosial ekonomi dengan prestasi belajar.

\section{HASIL PENELITIAN \\ Karakteristik subjek penelitian}

Tabel 1. Karakteristik subjek penelitian $(n=85)$

\begin{tabular}{|c|c|c|}
\hline Karakteristik & $\mathbf{n}$ & $\%$ \\
\hline \multicolumn{3}{|l|}{ Jenis kelamin } \\
\hline Laki-laki & 41 & 48,2 \\
\hline Perempuan & 44 & 51,8 \\
\hline \multicolumn{3}{|l|}{ Usia } \\
\hline 9 tahun & 16 & 18,8 \\
\hline 10 tahun & 20 & 23,5 \\
\hline 11 tahun & 29 & 34,2 \\
\hline 12 tahun & 20 & 23,5 \\
\hline \multicolumn{3}{|l|}{ Pendidikan ibu } \\
\hline Rendah & 63 & 74,1 \\
\hline Tinggi & 22 & 25,9 \\
\hline \multicolumn{3}{|l|}{ Pendidikan ayah } \\
\hline Rendah & 52 & 61,2 \\
\hline
\end{tabular}


Tinggi

Pekerjaan ibu

Tidak

bekerja

Bekerja

Pekerjaan ayah

Tidak

bekerja

Bekerja

Pengeluaran

perkapita

Rendah

Tinggi

Pola makan

Buruk

Sedang

Baik

Prestasi belajar

Kurang

Baik
30

34

51

34

50

1

45

40
35,3

40

60

92,9

61,2

38,8

40

58,8

1,2

52,9

47,1
Penelitian ini melibatkan 85 anak Sekolah Dasar usia 9-12 tahun yang stunting atau z-skor $\mathrm{TB} / \mathrm{U} \leq-2$ standar deviasi (SD) menurut WHO 2007 sebagai subjek penelitian. Rata-rata zskor $\mathrm{TB} / \mathrm{U}$ adalah $-2,75 \pm 0,69$ dengan nilai terendah $-5,85$ dan tertinggi $-2,05$. Di dalam penelitian ini terdapat 20 anak $(23,5 \%)$ severe stunting $(\mathrm{TB} / \mathrm{U} \leq$ $-3 \mathrm{SD})$.

Proporsi anak perempuan pada sampel lebih tinggi $(51,8 \%)$ dari pada proporsi anak lakilaki. Proporsi orang tua sampel dengan pendidikan yang rendah, yaitu hanya sampai tamat SMP, lebih tinggi (ibu $74,1 \%$; ayah $61,2 \%$ ) daripada orang tua yang tamat SMA dan pendidikan akademi/perguruan tinggi dan lebih dari setengah orang tua sampel bekerja (ibu 60\%; ayah 92,9\%). Namun, sebesar 61,2\% keluarga subjek mempunyai pengeluaran perkapita rendah.
Sebesar 40\% (n=34) subjek memiliki kategori pola makan yang buruk menurut kategori CFGHE sebesar $58,8 \%(n=50)$ memiliki kategori pola makan sedang dan $1,2 \% \quad(n=1)$ memiliki kategori pola makan baik. Proporsi subjek dengan prestasi belajar kurang adalah sebesar 52,9\% dan proporsi subjek dengan prestsi belajar baik sebesar 47,1\% (Tabel 1).

\section{Pola makan dan prestasi belajar}

Pola makan subjek penelitian dibandingkan dengan anjuran setiap kelompok makanan dan didapatkan bahwa sebagian besar subjek memenuhi anjuran untuk makan pokok $(55,3 \%)$ dan daging dan alternatifnya $(97,6 \%)$. Namun untuk sayur dan buah serta susu hampir semua subjek tidak memenuhi kriteria anjuran. Proporsi subjek yang tidak memenuhi anjuran untuk kelompok sayur dan buah sebesar 89,4\% dan 96,5\% untuk kelompok susu (Tabel 2).

Tabel 2. Deskripsi konsumsi kelompok makanan

\begin{tabular}{lcccc}
\hline \multirow{2}{*}{ Kelompok makanan } & \multicolumn{2}{c}{ Sesuai anjuran } & \multicolumn{2}{c}{ Tidak sesuai anjuran } \\
\cline { 2 - 5 } & $\mathbf{N}$ & $\mathbf{\%}$ & $\mathbf{n}$ & $\mathbf{\%}$ \\
\hline Makanan pokok & 47 & 55,3 & 38 & 44,7 \\
Sayur dan buah & 9 & 10,6 & 76 & 89,4 \\
Susu & 3 & 3,5 & 82 & 96,5 \\
Daging dan alternatifnya & 83 & 97,6 & 2 & 2,4 \\
\hline
\end{tabular}


Tabel 3 menunjukkan hubungan antara kelompok makanan dengan prestasi belajar. Uji chi square menunjukkan bahwa tidak terdapat hubungan yang signifikan antara keempat kelompok makanan dengan prestasi belajar.
Namun hasil analisis faktor risiko menunjukkan bahwa anak yang mengonsumsi sayur dan buah yang tidak sesuai dengan anjuran mempunyai risiko 1,214 kali untuk memperoleh prestasi belajar kurang.

Tabel 3. Hubungan kelompok makanan dengan prestasi belajar

\begin{tabular}{|c|c|c|c|c|c|c|c|}
\hline & \multicolumn{4}{|c|}{ Prestasi belajar } & \multirow{3}{*}{$\mathbf{X}^{2}$} & \multirow{3}{*}{$\mathbf{p}$} & \multirow{3}{*}{$\mathbf{R P}$} \\
\hline & \multicolumn{2}{|c|}{ Kurang } & \multicolumn{2}{|c|}{ Baik } & & & \\
\hline & $\mathbf{n}$ & $\%$ & $\mathbf{n}$ & $\%$ & & & \\
\hline \multicolumn{8}{|l|}{ Makanan pokok } \\
\hline Tidak sesuai anjuran & 18 & 21,2 & 20 & 23,5 & 0,857 & 0,355 & 0,825 \\
\hline Sesuai anjuran & 27 & 31,8 & 20 & 23,5 & & & \\
\hline \multicolumn{8}{|l|}{ Sayur dan buah } \\
\hline Tidak sesuai anjuran & 41 & 48,2 & 35 & 41,2 & 0,292 & 0,589 & 1,214 \\
\hline Sesuai anjuran & 4 & 4,7 & 5 & 5,9 & & & \\
\hline \multicolumn{8}{|l|}{ Susu } \\
\hline Tidak sesuai anjuran & 42 & 49,4 & 40 & 47,1 & 2,764 & 0,244 & 0,512 \\
\hline Sesuai anjuran & 3 & 3,5 & 0 & 0 & & & \\
\hline \multicolumn{8}{|l|}{ Daging dan alternatif } \\
\hline Tidak sesuai anjuran & 0 & 0 & 2 & 2,4 & 2,304 & 0,218 & \\
\hline Sesuai anjuran & 45 & 52,9 & 38 & 44,7 & & & \\
\hline
\end{tabular}

Hubungan antara pola makan dan prestasi belajar subjek dapat dilihat pada Tabel 4. Terdapat $16(18,8 \%)$ subjek dengan pola makan buruk memiliki prestasi belajar kurang, dan $18(21,2 \%)$ subjek dengan pola makan yang buruk memiliki prestasi belajar yang baik. Subjek dengan pola makan sedang+baik, terdapat $29(34,1 \%)$ yang berprestasi belajar kurang, dan 22 (25,9\%) berprestasi belajar baik.

Tabel 4. Hubungan pola makan dengan prestasi belajar

\begin{tabular}{llccccccc}
\hline & & \multicolumn{3}{c}{ Prestasi belajar } & & $\mathbf{X}^{2}$ & p & \multirow{2}{*}{ RP } \\
\cline { 3 - 6 } & & \multicolumn{2}{c}{ Kurang } & & & \\
\cline { 3 - 6 } & & $\mathbf{N}$ & $\mathbf{\%}$ & $\mathbf{n}$ & $\mathbf{\%}$ & & & \\
\hline \multirow{2}{*}{ Pola makan } & Buruk & 16 & 18,8 & 18 & 21,2 & 0,787 & 0,375 & 0,828 \\
& Sedang + baik & 29 & 34,1 & 22 & 25,9 & & & \\
\hline
\end{tabular}

Hasil uji statistik chi square diperoleh nilai $\mathrm{X}^{2}=0,787$ dan nilai $\mathrm{p}=0,375$ maka secara statistik dapat disimpulkan bahwa tidak terdapat hubungan antara pola makan dengan prestasi belajar subjek. Analisis faktor risiko menunjukkan bahwa pola makan buruk merupakan faktor protektif terhadap prestasi belajar kurang, atau anak dengan pola makan buruk mempunyai risiko
0,828 kali lebih besar untuk mendapatkan prestasi belajar yang kurang $(\mathrm{RP}=0,828)$.

\section{Status sosial ekonomi keluarga dan prestasi} belajar

Hubungan sosial ekonomi orang tua dengan prestasi belajar subjek dapat dilihat pada Tabel 5. 
Tabel 5. Hubungan pendidikan dan pekerjaan orang tua dengan prestasi belajar

\begin{tabular}{|c|c|c|c|c|c|c|c|}
\hline \multirow{3}{*}{ Variabel } & \multicolumn{4}{|c|}{ Prestasi belajar } & \multirow{3}{*}{$\mathbf{X}$} & \multirow{3}{*}{$\mathbf{p}$} & \multirow{3}{*}{$\mathbf{R P}$} \\
\hline & \multicolumn{2}{|c|}{ Kurang } & \multicolumn{2}{|c|}{ Baik } & & & \\
\hline & $\mathbf{n}$ & $\%$ & $\mathbf{n}$ & $\%$ & & & \\
\hline \multicolumn{8}{|l|}{ Pendidikan ibu } \\
\hline Rendah & 37 & 43,5 & 26 & 30,6 & 3,274 & 0,07 & 1,615 \\
\hline Tinggi & 8 & 9,4 & 14 & 16,5 & & & \\
\hline \multicolumn{8}{|l|}{ Pendidikan ayah } \\
\hline Rendah & 28 & 34,1 & 24 & 29,3 & 0,002 & 0,964 & 1,01 \\
\hline Tinggi & 16 & 19,5 & 14 & 17,1 & & & \\
\hline \multicolumn{8}{|l|}{ Pekerjaan ibu } \\
\hline Tidak bekerja & 18 & 21,2 & 16 & 18,8 & 0,0001 & 1 & 1 \\
\hline Bekerja & 27 & 31,8 & 24 & 28,2 & & & \\
\hline \multicolumn{8}{|l|}{ Pekerjaan ayah } \\
\hline Tidak bekerja & 1 & 1,2 & 2 & 2,4 & 0,517 & 0,594 & 0,612 \\
\hline Bekerja & 43 & 52,4 & 36 & 43,9 & & & \\
\hline \multicolumn{8}{|l|}{ Pengeluaran perkapita } \\
\hline Rendah & 26 & 30,6 & 26 & 30,6 & 0,465 & 0,495 & 0,868 \\
\hline Tinggi & 19 & 22,4 & 14 & 16,5 & & & \\
\hline
\end{tabular}

Hasil uji chi square pada tabel 5 menunjukkan bahwa tidak terdapat hubungan yang signifikan antara pendidikan orang tua, pekerjaan orang tua dan pengeluaran perkapita keluarga dengan prestasi belajar ( $\mathrm{p}$ value $>0,05$ ). Analisis faktor risiko menunjukkan subjek dengan ibu yang memiliki pendidikan yang rendah mempunyai risiko sebesar 1,615 kali untuk mendapatkan prestasi belajar kurang $(\mathrm{RP}=1,615)$. Pengeluaran perkapita keluarga yang rendah merupakan faktor protektif prestasi belajar anak kurang, atau anak yang tinggal di keluarga dengan pengeluaran perkapita rendah berisiko 0,868 kali memperoleh prestasi belajar kurang $(\mathrm{RP}=0,868)$.

\section{PEMBAHASAN}

Hasil penelitian ini menunjukkan bahwa tidak terdapat hubungan antara pola makan dengan prestasi belajar. Hasil ini berbeda dengan beberapa penelitian lain mengenai pola makan dengan prestasi belajar. Penelitian pada anak SMP di Malang menunjukkan bahwa anak yang makan tiga kali sehari dengan jenis makanan yang lengkap (makanan pokok, sayur, buah, protein hewani dan protein nabati) prestasi belajarnya lebih baik dibandingkan anak yang tidak makan tiga kali sehari. $^{20}$

Pemilihan jenis makanan juga berpengaruh terhadap prestasi belajar anak. Penelitian pada anak usia 13-15 tahun di Islandia telah menemukan bahwa pola makan makanan yang tidak sehat, seperti makana tinggi lemak dan gula, berpengaruh terhadap rendahnya prestasi belajar. ${ }^{21}$ Sebaliknya, penelitian di Kanada dan Palestina dengan subjek anak usia sekolah dasar juga menemukan bahwa menkonsumsi sayur dan buah berkaitan dengan prestasi belajar yang baik. $^{11,13,21}$

Canada's Food Guide to Healthy Eating (CFGHE) mengelompokkan jenis makanan kedalam empat kelompok. Keempat kelompok tersebut yaitu kelompok makanan pokok, sayur dan buah, susu, serta kelompok daging dan alternatif. Keempat kelompok makanan ini mempunyai peran terhadap prestasi belajar anak. Makanan pokok menyediakan glukosa yaitu sumber energi utama otak. Pemenuhannya dibutuhkan sehingga otak dapat bekerja secara maksimal. ${ }^{22}$ Sayur dan buah menyediakan mineralmineral mikro seperti tiamin dan zat besi yang berperan membantu memberikan suplay oksigen dan energi untuk otak. ${ }^{23,24}$ Mikronutrien lainnya adalah zink yang berperan sebagai komponen beberapa protein dan berfungsi untuk penyampaian sinyal intraseluler dalam otak. ${ }^{23}$ Selain itu masih terdapat mikrobutrien lain seperti folat, asam pantotenat, dan vitamin B6 yang membantu kinerja otak. $^{22}$ Susu dan daging serta alternatifnya menyediakan protein dan lemak yang berfungsi sebagai penyusun struktur sel otak dan neurotransmiter khususnya asam lemak essensial seperti docosahexaeonic acid (DHA) dan 
arachidonic acid (AA). ${ }^{22,25}$ Mineral lain yang terkandung adalah yodium. Yodium banyak terdapat pada ikan dan hasil laut lainnya. Yodium dibutuhkan untuk mensintesis hormon tiroid yang dibutuhkan untuk perkembangan sistem syaraf pusat. ${ }^{23}$

Data yang diperoleh dari penelitian ini menunjukkan bahwa konsumsi sayur dan buah serta susu dan alternatif yang sesuai dengan anjuran CFGHE masih sangat rendah. Hasil analisis hubungan konsumsi sayur dan buah terhadap prestasi belajar pun menunjukkan bahwa tidak terdapat hubungan yang signifikan. Namun analisis faktor risiko menunjukkan bahwa konsumsi sayur dan buah yang rendah mempunyai risiko sebesar 1,214 kali lebih besar untuk mendapat prestasi belajar kurang. Penelitian di Taiwan menunjukkan bahwa konsumsi kedua kelompok makanan ini, yakni susu dan alternatif serta sayur dan buah, mempunyai hubungan positif dengan prestasi belajar. ${ }^{12} \mathrm{Hal}$ ini didukung oleh penelitian di Kanada dan Palestina yang menunjukkan bahwa asupan sayur dan buah memiliki hubungan positif dengan prestasi belajar. Anak yang asupan sayur dan buahnya tinggi akan cenderung memiliki prestasi belajar yang baik dan kemungkinan untuk gagal didalam ujian rendah. ${ }^{11,13}$

Status sosial ekonomi keluarga juga merupakan salah satu variabel yang mempunyai peran dalam kaitannya dengan prestasi belajar anak. Status sosial ekonomi keluarga ditentukan oleh tingkat pendidikan, pekerjaan, dan pendapatan anggota keluarga. ${ }^{26}$ Hasil penelitian ini menunjukkan bahwa tidak terdapat hubungan yang signifikan antara pendidikan orang tua dengan prestasi belajar anak. Walaupun tidak signifikan, pendidikan orang tua yang rendah merupakan faktor risiko prestasi belajar anak kurang. Hal ini berbeda dengan hasil penelitian di Kanada dan Korea yang menunjukkan bahwa semakin tinggi pendidikan orang tua semakin baik juga prestasi belajar anak..$^{13,15}$

Penelitian ini menunjukkan bahwa tidak terdapat hubungan yang signifikan antara pendapatan yang dilihat dari pengeluaran perkapita keluarga dengan prestasi belajar anak. Hasil yang bertentangan ditunjukkan pada penelitian yang dilakukan di Kanada dan Taiwan yang mengungkapkan bahwa pendapatan orang tua secara signifikan berpengaruh terhadap prestasi belajar anak. Orang tua dengan pendapatan yang tinggi berhubungan dengan prestasi anak yang tinggi juga. ${ }^{13}$ Sedangkan pendapatan orang tua yang rendah berkaitan dengan rendahnya waktu untuk anak, pengetahuan tentang gizi, daya beli makanan sehat yang berakibat pada rendahnya pola makan dan prestasi belajar anak. ${ }^{12}$

Hasil analisis faktor risiko menunjukkan bahwa pengeluaran perkapita keluarga yang rendah merupakan faktor protektif anak untuk mendapatkan prestasi belajar yang kurang. Anak yang berasal dari keluarga dengan pengeluaran perkapita rendah berpeluang 0,868 kali mendapatkan prestasi belajar yang kurang. Keadaan ekonomi keluarga yang rendah bukan hanya menjadi faktor penghambat anak untuk belajar, tetapi bisa juga menjadi faktor pendorong dan motivator anak untuk lebih giat belajar supaya mendapat prestasi belajar yang lebih baik. Pada anak dengan pendapatan keluarga tinggi perhatian anak terhadap pelajaran mungkin akan berkuarang karena anak bisa mendapatkan hal-hal yang diinginkan, berupa mainan atau pergi ke tempattempat hiburan dengan mudah. Kemudahan akses untuk bermain ini bisa membuat anak malas untuk belajar. $^{19}$

Hubungan pola makan dengan prestasi belajar dan hubungan status sosial ekonomi keluarga dengan prestasi belajar yang tidak signifikan serta perbedaan dengan beberapa penelitian sebelumnya disebabkan oleh perbedaan subjek penelitian yang diambil. Penelitian ini mengkhususkan pada prestasi belajar anak stunting. Anak yang stunting cenderung memiliki kemampuan kognitif yang rendah, dan proses perkembangan kognitif yang lambat. Perkembangan kognitif yang mengalami keterlambatan pada anak stunting dapat juga berakibat pada gangguan kognitif secara permanen. ${ }^{5}$ Stunting erat hubungannya dengan rendahnya kemampuan kognitif. Penelitian di India pada tahun 2008 anak dengan usia 5-10 tahun yang stunting memiliki kemampuan kognitif yang rendah dan proses perkembangan kognitif yang pelan. Selain rendahnya kemampuan kognitif, stunting juga berkaitan dengan tingginya permasalahan perilaku, rendahnya skor IQ, dan rendahnya prestasi belajar. ${ }^{5}$

Keadaan kognitif pada anak stunting inilah yang berkaitan dengan tidak signifikannya pola makan dan status sosial ekonomi keluarga dengan prestasi belajar anak stunting. Seperti penelitian di Yogyakarta pada anak stunting kelas IV-VI SD yang menunjukkan bahwa pemberian suplementasi Fe-folat dan zink tidak berpengaruh terhadap prestasi belajar anak stunting. ${ }^{27}$ 
Stunting bukanlah satu-satunya faktor yang mempengaruhi prestasi belajar anak. Prestasi belajar anak juga tergantung pada banyak faktor yang tidak dapat dikontrol yang dapat berpengaruh terhadap hasil penelitian. Beberapa faktor tersebut antara lain faktor dari dalam diri anak seperti minat anak, IQ, bakat dan motivasi anak. Selain itu faktor lingkungan masyarakat sekitar juga dapat berpengaruh terhadap prestasi belajar anak.

\section{SIMPULAN}

Penelitian ini menyimpulkan bahwa tidak terdapat hubungan antara pola makan dengan prestasi belajar anak stunting usia 9-12 tahun di Kelurahan Kemijen Semarang Timur ( $p$ value > $0,05)$. Selain itu, tidak terdapat juga hubungan antara status sosial ekonomi keluarga dengan prestasi belajar anak stunting usia 9-12 tahun di Kelurahan Kemijen Semarang Timur ( $\mathrm{p}$ value > $0,05)$.

\section{SARAN}

Perlu peran orang tua untuk membantu meningkatkan prestasi belajar pada anak stunting usia 9-12 tahun di Kemijen Semarang Timur. Orang tua harus meluangkan waktu dan berperan aktif dalam membantu anak belajar sehingga bisa mendapatkan prestasi belajar yang lebih baik. Orang tua juga perlu memberikan dan mencontohkan pola makan yang baik yaitu pola makan yang sesuai dengan anjuran untuk setiap kelompok makanannya dan sehat khususnya pada anak stunting sehingga dapat mendukung aktivitas, dan juga kesehatannya.

\section{UCAPAN TERIMAKASIH}

Penulis mengucapkan terimakasih kepada anak dan orang tua yang sudah berkenan menjadi subjek dan responden di dalam penelitian ini. Terimakasih juga kepada Kepala Sekolah serta staff pengajar SD N Kemijen 01, SD N Kemijen 02, SD N Kemijen 03 dan SD N Kemijen 04 atas ijin yang telah diberikan dan atas kerjasamanya dalam penelitian. Terimakasi kepada orang tua dan keluarga atas doa dan dukungan yang telah diberikan.

\section{DAFTAR PUSTAKA}

1. WHO. Nutrition Landscape Information System (NLIS) Country Profile Indicators: Interpretation Guide. Switzerland: WHO press; 2010.

2. Arisman. Gizi dalam Daur Kehidupan: Buku Ajar Ilmu Gizi. Jakarta: Buku Kedokteran EGC; 2004.
3. Badan Penelitian dan Pengembangan Kesehatan Departeman Kesehatan RI. Laporan hasil Riset Kesehatan Dasar 2010. Jakarta; 2010.

4. Dinas Kesehatan. Profil Kesehatan Kota Semarang 2011. Semarang; 2011.

5. Kar BR, Rao SL, Chandramouli BA. Cognitive Development in Children with Chronic Protein Energy Malnutrition. Behavioral and Brain Functions 2008, 4:31.

6. Hioui ME, Azzaoui FZ, Ahami OT, Aboussaleh Y. Nutritional Status and School Achievements in Rural Area of Anti-Atlas, Maroko. Food and Nutrition Sciences. 2011; 2: 878-83.

7. Brito GNO, Onis M. Growth Status, Behavior and Neuropsychological Performance: a Study of Brazilian School Age Children. Arq Neuropsiqulatr. 2004; 62 (4): 949-54.

8. Webb KE, Horton NJ, Katz DL. Parental IQ and Cognitive Development of Malnourished Indonesian Children. European Journal of Clinical Nutrition. 2005; 59: 618-120.

9. Daniels MC, Adair LS. Growth in Young Filipino Children Predicts Schooling Trajectories through High School. American Society for Nutritional Sciences. 2004; 4: 0022-3166.

10. Victoria CG, Adair L, Fall C, Hallal PC, Martorell R, Richter L, et al. Maternal and Child Undernutrition: Consequences for Adult Health and Human Capital. Lancet. 2008 January 26; 371(9609): 340-57.

11. Abudayya A, Shi Z, Abed Y, Holmboe-Ottesen G. Diet, Nutritional Status and School Perfomance Among Adolescents in Gaza Strip. Eastern Mediterranean Health Journal. 2011; 17:3.

12. Fu ML, Cheng L, Tu SH, Pan WH. Association Between Unhealthful Eating Patterns and Unfavorable Overall School Performance in Children. Journal of the American Dietetic Association. 2007; 107: 1935-43.

13. Florence MD, Asbridge M, Veugelers PJ. Diet Quality and Academic Performance. Journal of School Health. April 2008, 78:4.

14. Caro DH. Socio-Economic Status and Academic Achievement Trajectories from Childhood to Adolescence. Canadian Journal of Education. 2009; 32,3: 558-90.

15. Kim HYP, Frongillo EA, Han SH, Oh SY, Kim WK, Jang YA, et al. Academic Performance of Korean Children is Associated with Dietary Behaviours and Physical Status. Asia Pacific Journal Clinical Nutrition. 2003; 12 (2): 186-192.

16. Canada's Food Guide. www.hc-sc.gc.ca

17. Storey KE, ForbesLE, Fraser SN, Spence JC, Plotnikoff RC, Raine KD, et al. Diet Quality, Nutrition and Physical Activity Among Adolescents the Web-SPAN (Web-Survey of 
Physical Activity and Nutrition) Project. Public Health Nutrition. 2009; 12(11)

18. Badan Pusat Statistik. Survei Sosial Ekonomi Nasional 2011. Jakarta; 2011.

19. Minatun, Sri. Faktor-Faktor yang Berhubungan dengan Prestasi Belajar Siswa Kelas IV dan V MI Negeri 02 Cempaka Putih Ciputat Timur Tahun Ajaran 2010/2011 (Skripsi). Universitas Islam Negeri Syarif Hidayatullah. 2011

20. Masdewi, Devi M, Setiawati T. Korelasi Perilaku Makan dan Status Gizi Terhadap Prestasi Belajar Siswa Program Akselerasi di SMP. Teknologi dan Kejuruan. 2011; 34(2)

21. Sigfusdottir ID, Kristjansson AL, Allegrante JP. Health Behaviour and Academic Achievement in Icelandic School Children. Oxford University Press. 2006; 22(1): 70-80

22. Mahan LK, Escott-Stump S. Krause's Food and Nutrition Therapy. $12^{\text {th }}$ ed. Saunders Elsevier: 2008.

23. Prado E, Dewey K. Nutrition and Brain Development in Early Life. A\&T Technical Brief Issue 4, Januari 2012. www.aliveandthrive.org

24. Lozoff B, Beard J, Connor J, Felt B, Georgieff M, Schallert T. Long-Lasting Neural and Behavioral Effects of Iron Deviciency in Infancy. Nutrition Reviews. 2006; 64(5 Pt 2): S34-43

25. Uauy R, Dangour AD. Nutrition in Brain Development and Aging: Role of Essential Fatty Acids. Nutr Rev. 2006; 64(5 Pt 2): S24

26. Abdulsyani. Sosiologi Skematika, Teori dan Terapan. Jakarta: Bumi Aksara. 1994.

27. Ismail, Elza. Pengaruh Suplementasi Fe-Folat, Zink dan Vitamin A Terhadap Prestasi Belajar Siswa Stunted Kelas IV-VI Sekolah Dasar (Tesis). Universitas Gadjah Mada. 2004 